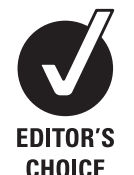
CHOICE

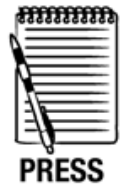

RELEASE

\title{
The national heart failure audit for England and Wales 2008-2009
}

\author{
John G F Cleland, ${ }^{1}$ Theresa McDonagh, ${ }^{2}$ Alan S Rigby, ${ }^{1}$ Ashraf Yassin, ${ }^{1}$ \\ Tracy Whittaker, ${ }^{3}$ Henry J Dargie, ${ }^{4}$ on behalf of the National Heart Failure \\ Audit Team for England and Wales
}

\begin{abstract}
See Editorial, p 865
${ }^{1}$ Department of Cardiology, Castle Hill Hospital, Hull York Medical School, University of Hull, Kingston-upon-Hull, UK ${ }^{2}$ Imperial College London, Cardiology Department, Royal Brompton \& Harefield NHS Trust, London, UK

${ }^{3}$ The National Health Service Information Centre, London, UK ${ }^{4}$ Scottish Advanced Heart Failure Service, Golden Jubilee National Hospital, Clydebank, West Dunbartonshire, UK

\section{Correspondence to}

Professor John G F Cleland, Department of Cardiology, Hull York Medical School, University of Hull, Castle Hill Hospital, Cottingham, Kingston-upon-Hull HU16 5J0, UK:

j.g.cleland@hull.ac.uk
\end{abstract}

Accepted 28 September 2010 Published Online First 20 December 2010

\section{ABSTRACT}

Objectives To obtain national data on the clinical characteristics, investigation, management and outcome of patients hospitalised with a diagnosis of heart failure. Method A survey was carried out of the first 10 patients hospitalised with a primary diagnosis of heart failure each month in 86 hospitals providing services for acute medical admissions in England and Wales from April 2008 until March 2009. The main outcome measures were rates of investigations, treatments and specialist management, length of hospital stay and mortality. Results The 86 hospitals enrolled 6170 patients with a median age of 78 years (IOR 70-85 years), including 2639 (43\%) women. At admission, only 30\% of patients were breathless at rest, while $43 \%$ had peripheral oedema. Echocardiograms were recorded in $75 \%$ of patients and left ventricular ejection fraction (LVEF) was $\leq 40 \%$ in $78 \%$. Natriuretic peptides were rarely measured. Allowing for missing data, $>90 \%$ of patients were treated with loop diuretics at discharge, $80 \%$ with ACE inhibitors or angiotensin receptor blockers, $50 \%$ with $\beta$-blockers and $30 \%$ with aldosterone antagonists. Patients with an LVEF $<40 \%$ were more likely to receive these agents. Median hospital stay was 9 days (IOR $5-17)$ and in-patient mortality was $12 \%$. Patients admitted to general medicine rather than cardiology wards were more likely to die $(\mathrm{HR}=2.5,95 \% \mathrm{Cl} 2.0$ to 3.3, $\mathrm{p}<0.001)$ even after adjusting for differences $(\mathrm{HR}=1.9,95 \% \mathrm{Cl} 1.5$ to $2.5, \mathrm{p}<0.001)$. Projected 1 -year mortality below and above age 75 years was $26 \%$ and $56 \%$, with higher rates if managed on general medicine rather than cardiology wards $(\mathrm{HR}=1.4,95 \% \mathrm{Cl} 1.2$ to 1.6, $\mathrm{p}<0.001)$.

Conclusion The prognosis of patients hospitalised with heart failure remains poor and investigation and treatment suboptimal. Specialist services are associated with higher rates of investigation and treatment and improved outcome.

\section{INTRODUCTION}

Despite advances in diagnosis and management, heart failure remains a common but complex syndrome associated with high rates of hospitalisation and death. In England and Wales, with a combined population of $\sim 50$ million in 2006-2007, more than 250,000 hospital deaths and discharges were coded for heart failure, more than 65,000 of these in the first diagnostic position. ${ }^{1}$ For an average hospital trust, which serves a community of $\sim 300000$ people, this represents about 1500 episodes each year, with about 400 in the first diagnostic position. Assuming an average length of stay in excess of 10 days, this reflects $\sim 2.5$ million bed-days per year overall and about 15,000 bed-days per year for each hospital trust. Assuming a cost of at least $£ 225$ per bed-day, ${ }^{2}$ this part of the cost of managing heart failure could alone amount to $£ 563$ million nationally and $£ 3.4$ million per hospital trust per year. These data probably underestimate true activity. ${ }^{3}$

In order to gain greater insight into the contemporary epidemiology, diagnosis and management of patients hospitalised with heart failure, the British Society for Heart Failure, the HealthCare commission and the National Health Service (NHS) Information Centre joined forces to develop, pilot and deploy an audit of patients with a death or discharge diagnosis of heart failure in England and Wales. A similar audit is being conducted in Scotland. Following pilot studies using different entry criteria, a uniform set of criteria for patient inclusion was agreed and implemented in March 2008. This is a report of the first year's activity.

\section{METHODS}

The NHS Information Centre developed a secure, encrypted, web-based database using Lotus Notes for the collection of data relating to patients with heart failure. The full data set includes 233 fields and can be used as a patient electronic record. For audit purposes, 21 fields were designated as core fields, of which seven comprised basic demographic information such as patient identifiers, sex and date of enrolment. A list of core fields is shown in figure 1.

The purpose of the survey was to assess the quality of care of patients with heart failure by gathering information on the rate of diagnostic investigations, treatment with medicines at discharge, referral to specialist services for continuing care, treatment ward and length of stay. All-cause mortality during and subsequent to hospitalisation, with a maximum potential followup of 1 year, was recorded.

Various methods of patient identification were considered including enrolment from outpatient clinics and hospital wards of patients in whom a definite or provisional diagnosis of heart failure had been made, but such a strategy could not address any deficiency in the diagnostic process and might enrol patients with an unrepresentatively high quality of care. Inclusion of all patients receiving a loop diuretic, patients in whom heart failure should be excluded, was considered, but pilot studies suggested that this was likely to be 
Figure 1 Mandatory fields for completion of the 2008-2009 audit. Note that mandatory fields could be completed as unknown.

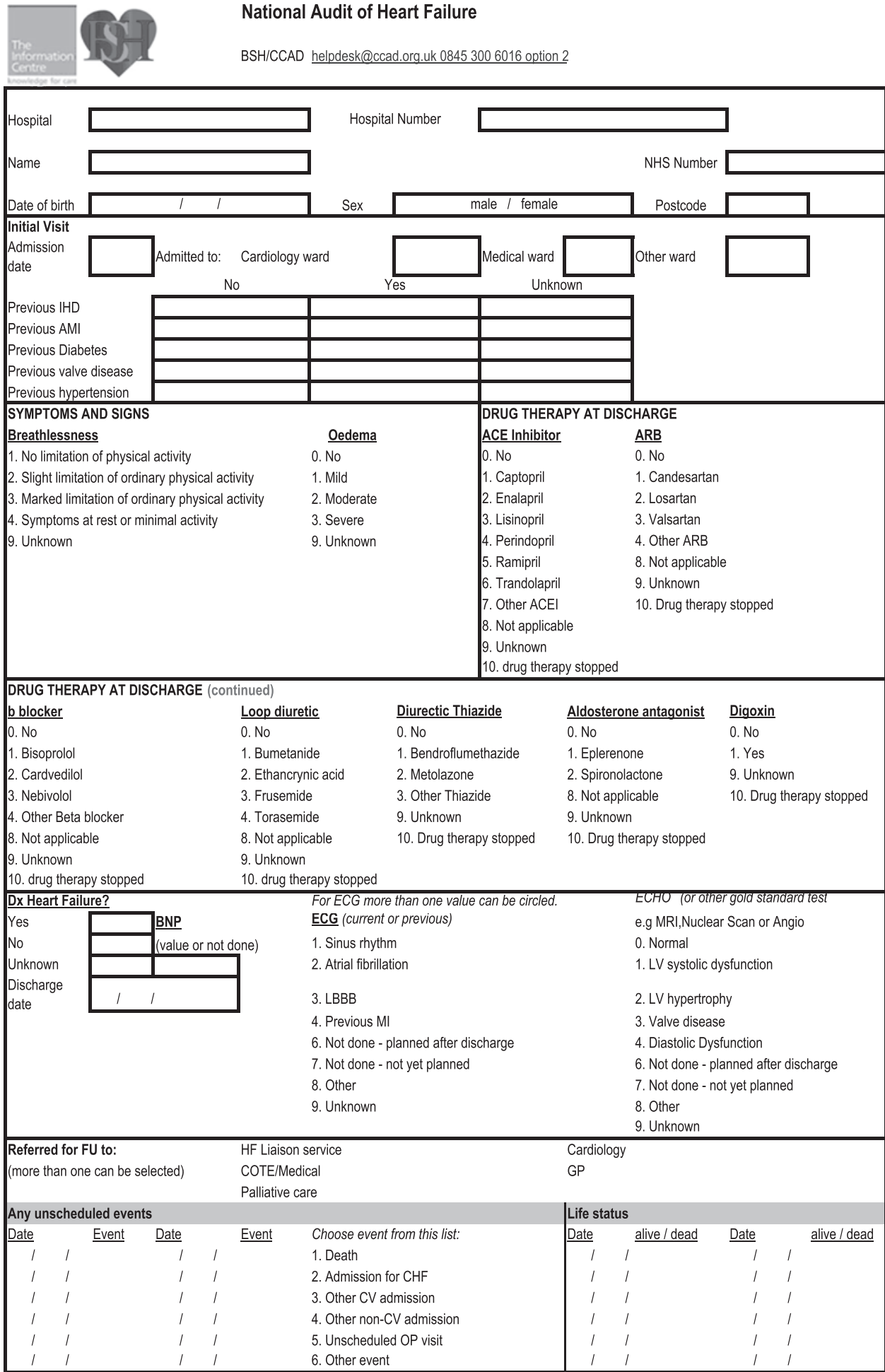

a large number of patients and not readily feasible at this time. ${ }^{4}$ Another possibility was to enrol all patients with a death or discharge diagnosis of heart failure in any coding position (up to 14 diagnoses can be coded for each patient), since a diagnosis of heart failure in any position carries a similar prognosis and it is a matter of judgement whether to code heart failure in the first or lower position. This would require recording information on $\sim 250,000$ episodes per year and was also considered not feasible. Ultimately, a pragmatic decision was taken to focus only on patients with heart failure coded in the first position at death or discharge. During 2008/2009, participating hospitals were asked to provide data on the first 10 patients with a death or discharge diagnosis of heart failure in each month. If all hospital trusts dealing with adult general or cardiology admissions (166) in England and Wales complied with this request, this would generate $\sim 20000$ submissions from 10000-15000 patients. The intention is to code all patients with a death or discharge code of heart failure in the first diagnostic coding position from April 2010 onwards.

This is a national survey initiated by the NHS Information Centre and therefore no specific request for ethical approval from regulators was deemed necessary nor was patient consent 
Table 1 Characteristics of all patients by age, sex and admission ward

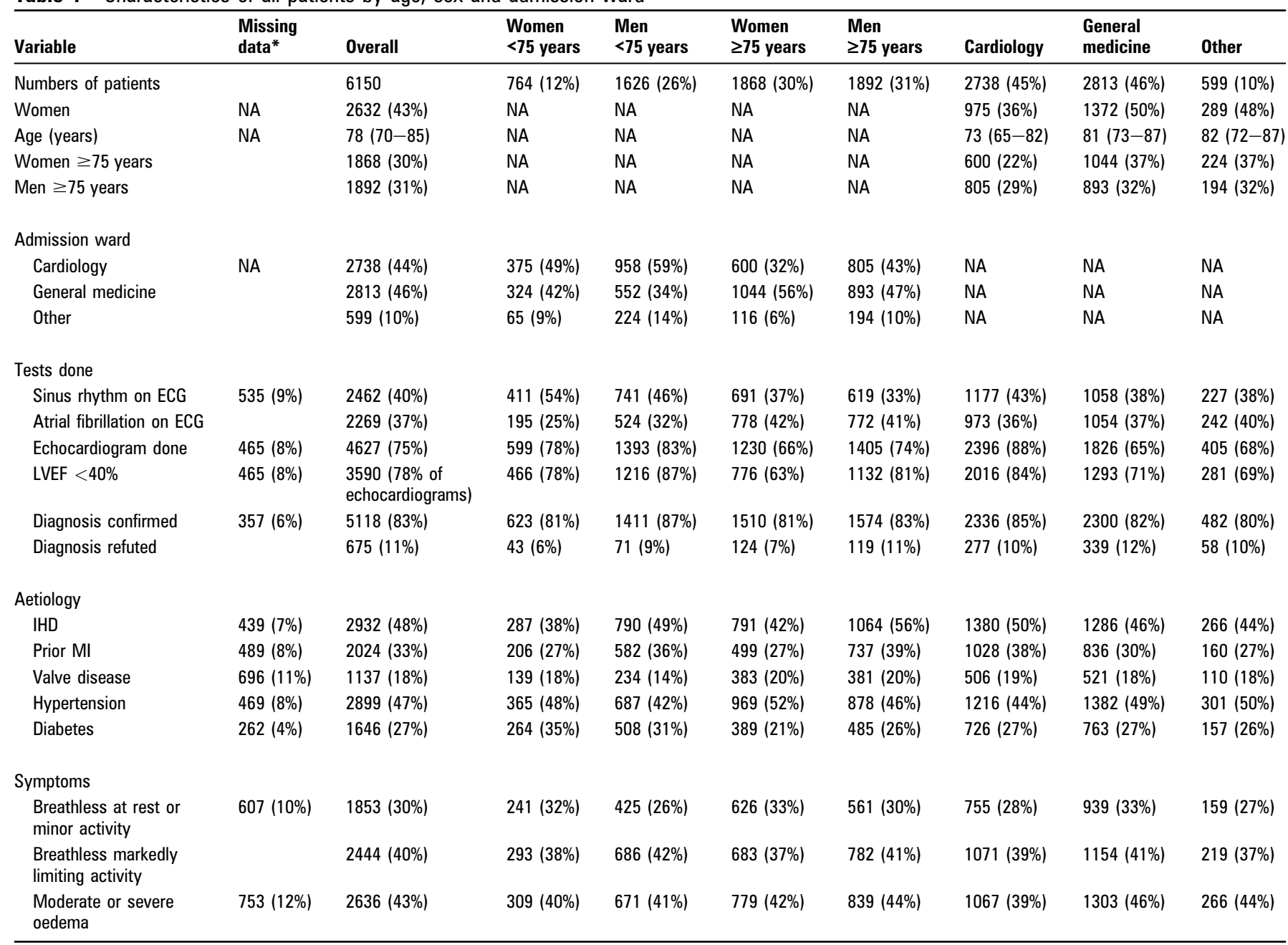

Data are median and IQR or numbers and percentages of the population for age and sex.

*Excluding six patients in whom sex was not recorded (all $<75$ years), eight in whom age was not recorded (four women, four men) and six in whom admission ward was not recorded). IHD, ischaemic heart disease; LVEF, left ventricular ejection fraction; MI, myocardial infarction; NA, not applicable.

sought. The NHS Information Centre acts as guarantor of patient anonymity and data security.

\section{Statistical methods}

Data were summarised using the median and IOR (continuous data) or by percentages for categorical data. Median length of stay and IOR excluded patients with an admission of $<24 \mathrm{~h}$ for whatever reason, including death, since it was unclear what proportion of these were elective admissions for planned procedures. Variables predicting the likelihood of being discharged on guideline treatment were modelled using logistic regression and backwards elimination. We are aware that automated selection methods are not optimal, ${ }^{5} 6$ though backwards elimination is preferable to forwards stepwise. ${ }^{7}$ Models were validated using re-sampling based on 10 -fold cross-validation. ${ }^{8}$ The data were divided into 10 subsets of approximately equal size. For each subset we generated a logistic regression model leaving out one subset at a time. The omitted subset was used to calculate a misclassification rate per model. Missing values for categorical variables generated a separate category which was included in the modelling. Analyses were conducted both in the overall population surviving to discharge and in the subpopulation with a reported left ventricular ejection fraction (LVEF) $<40 \%$, the main focus of therapeutic guidelines.
All-cause mortality was analysed by Cox regression from which HRs with 95\% CIs were estimated. Deaths were confirmed by the Office for National Statistics (ONS). The proportionality of hazards assumption was assessed by residual plotting. ${ }^{9}$ Two Cox models were undertaken. First, in patients who died on index admission (neither treatment on discharge nor postdischarge referral to cardiac/heart failure services were considered as covariates in this group). A second model was developed for patients surviving to discharge. Graphical presentation was by Kaplan-Meier curves. A nominal level of $5 \%$ statistical significance (two-tailed) was assumed. The Stata statistical computer package was used to analyse the data (StatCorp, Jacksonville, Florida, USA).

\section{RESULTS}

Eighty-six hospitals participated in this survey, reporting data on a median of 44 (IOR 13-111) patients. In the 12 months after 31 March 2008, 6170 patients were enrolled (compared with $\sim 10000$ had each hospital provided the expected 120 patients), of whom 2639 (43\%) were women (tables 1-4). The median age at first admission was 78 years (IOR 70-85 years) with $54 \%$ of men and $71 \%$ of women being aged $>75$ years. Ethnic origin was reported in 4063 patients (66\%) of whom 3727 (92\%) were Caucasian. 
Table 2 Characteristics of patients with LVEF $<40 \%$ by age, sex and admission ward

\begin{tabular}{|c|c|c|c|c|c|c|c|c|c|}
\hline Variable & $\begin{array}{l}\text { Missing } \\
\text { data* }^{*}\end{array}$ & Overall & $\begin{array}{l}\text { Women } \\
<75 \text { years }\end{array}$ & $\begin{array}{l}\text { Men } \\
<75 \text { years }\end{array}$ & $\begin{array}{l}\text { Women } \\
\geq 75 \text { years }\end{array}$ & $\begin{array}{l}\text { Men } \\
\geq 75 \text { years }\end{array}$ & Cardiology & $\begin{array}{l}\text { General } \\
\text { medicine }\end{array}$ & Other \\
\hline Numbers of patients & & 3590 & $466(13 \%)$ & $1216(34 \%)$ & $776(21 \%)$ & $1132(32 \%)$ & $2016(56 \%)$ & $1293(36 \%)$ & $281(8 \%)$ \\
\hline Women & NA & $1242(35 \%)$ & NA & NA & NA & NA & $612(30 \%)$ & $533(41 \%)$ & $97(35 \%)$ \\
\hline Women $\geq 75$ years & & $776(32 \%)$ & NA & NA & NA & NA & $348(47 \%)$ & $364(28 \%)$ & $64(23 \%)$ \\
\hline Men $\geq 75$ years & & $1132(22 \%)$ & NA & NA & NA & NA & $609(30 \%)$ & $414(32 \%)$ & $109(39 \%)$ \\
\hline General medicine & & $1293(36 \%)$ & $169(36 \%)$ & $346(28 \%)$ & $364(49 \%)$ & $414(37 \%)$ & NA & NA & NA \\
\hline Other & & $281(8 \%)$ & $33(7 \%)$ & $75(6 \%)$ & $64(9 \%)$ & $109(10 \%)$ & NA & NA & NA \\
\hline \multicolumn{10}{|l|}{ Tests done } \\
\hline Sinus rhythm on ECG & $208(6 \%)$ & $1604(45 \%)$ & $279(60 \%)$ & $565(46 \%)$ & $335(46 \%)$ & $425(38 \%)$ & $920(45 \%)$ & $564(44 \%)$ & $120(43 \%)$ \\
\hline \multicolumn{10}{|l|}{ Aetiology } \\
\hline IHD & $198(6 \%)$ & $1861(53 \%)$ & $184(39 \%)$ & $610(50 \%)$ & $382(52 \%)$ & $685(61 \%)$ & $1058(53 \%)$ & $662(51 \%)$ & $141(50 \%)$ \\
\hline Prior Ml & $217(6 \%)$ & $1442(41 \%)$ & $154(33 \%)$ & 471 (39\%) & $283(38 \%)$ & $534(47 \%)$ & $838(42 \%)$ & 507 (39\%) & 97 (35\%) \\
\hline Valve disease & $296(8 \%)$ & $603(17 \%)$ & $78(17 \%)$ & $158(13 \%)$ & $158(21 \%)$ & $209(18 \%)$ & $321(16 \%)$ & $232(18 \%)$ & $50(18 \%)$ \\
\hline Hypertension & $233(7 \%)$ & $1638(46 \%)$ & $207(44 \%)$ & $483(40 \%)$ & 401 (55\%) & $547(48 \%)$ & 872 (43\%) & $634(49 \%)$ & $132(47 \%)$ \\
\hline Diabetes & $103(3 \%)$ & $991(28 \%)$ & $154(33 \%)$ & $361(30 \%)$ & $169(23 \%)$ & $307(27 \%)$ & $544(27 \%)$ & $367(28 \%)$ & $80(28 \%)$ \\
\hline \multicolumn{10}{|l|}{ Symptoms } \\
\hline $\begin{array}{l}\text { Breathless at rest or } \\
\text { minor activity }\end{array}$ & $322(9 \%)$ & $1035(29 \%)$ & $140(30 \%)$ & $305(25 \%)$ & $269(40 \%)$ & $321(28 \%)$ & $500(25 \%)$ & $472(36 \%)$ & $63(22 \%)$ \\
\hline $\begin{array}{l}\text { Breathless markedly } \\
\text { limiting activity }\end{array}$ & & $1491(42 \%)$ & $194(42 \%)$ & $528(43 \%)$ & $293(40 \%)$ & $476(42 \%)$ & $822(41 \%)$ & $565(43 \%)$ & $104(37 \%)$ \\
\hline $\begin{array}{l}\text { Moderate or } \\
\text { severe oedema }\end{array}$ & $385(11 \%)$ & $1437(40 \%)$ & $172(37 \%)$ & $474(39 \%)$ & $316(41 \%)$ & $475(42 \%)$ & 717 (36\%) & $606(48 \%)$ & $114(41 \%)$ \\
\hline
\end{tabular}

Data are median and IOR or numbers and percentages of the population for age and sex.

*Excluding six patients in whom sex was not recorded (all $<75$ years), eight in whom age was not recorded (four women, four men) and six in whom admission ward was not recorded). IHD, ischaemic heart disease; LVEF, left ventricular ejection fraction; MI, myocardial infarction; NA, not applicable.

Almost $50 \%$ of patients were managed on cardiology wards. Compared with patients on general medical wards, those managed on cardiology wards were younger and more likely to be men, were more likely to have echocardiography and to have left ventricular systolic dysfunction (LVSD), but rates of co-morbidity including ischaemic heart disease, atrial fibrillation and diabetes were similar. The diagnosis of heart failure provided by discharge codes was verified by site investigators in $81 \%$ of cases, with little difference according to age, sex, LVEF or admission ward.

Most patients had an ECG done (96\%). Echocardiograms were usually done in patients admitted to cardiology wards (88\%) but often not done on general medical wards (65\%). A higher proportion of echocardiograms from cardiology wards showed an LVEF $<40 \%$ (84\% vs $71 \%$ ). Only $1 \%$ of patients had a measurement of a natriuretic peptide. Overall, only $48 \%$ of patients were reported to have ischaemic heart disease and only $33 \%$ were reported to have had a prior myocardial infarction, although proportions were higher among men and younger patients. Hypertension was reported in $47 \%$, diabetes in $27 \%$ and valve disease in 19\%, and were more common among older patients. At the time of admission, only $30 \%$ of patients were reported to be breathless at rest, while $40 \%$ had breathlessness limiting ordinary activity and $43 \%$ had moderate or severe peripheral oedema. Symptom presentation differed little by age, sex or admission ward.

LVEF was not recorded in $25 \%$, was $<40 \%$ in $58 \%$ of all cases and $>40 \%$ in only $17 \%$. Patients with LVEF $>40 \%$ and those who had no reported LVEF had similar characteristics and were more likely to be women, older, managed on general medical wards and have atrial fibrillation and valve disease but less likely to have had a myocardial infarction compared with those with LVEF $<40 \%$. Symptoms at presentation differed little by LVEF group.

Treatment at discharge was reported in $\sim 90 \%$ of patients (table 5). Allowing for missing data, $>90 \%$ of patients were treated with loop diuretics at discharge regardless of age, sex or treatment ward. ACE inhibitors or angiotensin II receptor blockers (A2RBs) were prescribed in $\sim 80 \%$ of patients aged $<75$ years and $\sim 70 \%$ aged $\geq 75$ years without evidence of bias according to sex. $\beta$-Blockers were prescribed in only $50 \%$ of patients. Younger patients and men were more likely to receive them. Overall, $\sim 30 \%$ of patients were discharged on an aldosterone antagonist, with men and those admitted to cardiology wards more likely to receive them. Diuretics and A2RBs were prescribed in a similar proportion of patients regardless of whether LVEF was above or below $40 \%$ or not documented. Patients with a documented LVEF $<40 \%$ were more likely to receive ACE inhibitors, $\beta$-blockers and aldosterone antagonists than other patients.

The median stay in hospital when $>24 \mathrm{~h}$ was 9 days (IOR 5-17 days), but was slightly longer in older patients and shorter in patients admitted to general medical compared with cardiology wards (tables 6 and 7). Patients without a reported LVEF tended to have shorter hospital stays, but length of stay was similar in those with LVEF above or below $40 \%$. 
Table 3 Characteristics of patients with LVEF $\geq 40 \%$ by age, sex and admission ward

\begin{tabular}{|c|c|c|c|c|c|c|c|c|c|}
\hline & $\begin{array}{l}\text { Missing } \\
\text { data* }\end{array}$ & Overall & $\begin{array}{l}\text { Women } \\
<75 \text { years }\end{array}$ & $\begin{array}{l}\text { Men } \\
<75 \text { years }\end{array}$ & $\begin{array}{l}\text { Women } \\
\geq 75 \text { years }\end{array}$ & $\begin{array}{l}\text { Men } \\
\geq 75 \text { years }\end{array}$ & Cardiology & $\begin{array}{l}\text { General } \\
\text { medicine }\end{array}$ & Other \\
\hline Numbers of patients & & 1037 & $133(13 \%)$ & $177(17 \%)$ & $454(44 \%)$ & $273(27 \%)$ & $380(37 \%)$ & $533(51 \%)$ & $124(12 \%)$ \\
\hline Women & NA & $590(57 \%)$ & NA & NA & NA & NA & $206(54 \%)$ & $308(57 \%)$ & $76(60 \%)$ \\
\hline Women $\geq 75$ years & & $454(44 \%)$ & NA & NA & NA & NA & $143(38 \%)$ & $245(46 \%)$ & $66(53 \%)$ \\
\hline Men $\geq 75$ years & & $273(26 \%)$ & NA & NA & NA & NA & $93(24 \%)$ & $149(28 \%)$ & $31(25 \%)$ \\
\hline General medicine & & $533(51 \%)$ & $60(45 \%)$ & $79(44 \%)$ & $245(54 \%)$ & $149(54 \%)$ & NA & NA & NA \\
\hline Other & & $124(12 \%)$ & $10(8 \%)$ & $17(10 \%)$ & $66(15 \%)$ & $31(11 \%)$ & NA & NA & NA \\
\hline \multicolumn{10}{|l|}{ Tests done } \\
\hline Sinus rhythm on ECG & $74(7 \%)$ & $394(38 \%)$ & $63(47 \%)$ & $90(51 \%)$ & $159(35 \%)$ & $82(30 \%)$ & $148(39 \%)$ & $198(37 \%)$ & $48(38 \%)$ \\
\hline \multicolumn{10}{|l|}{ Aetiology } \\
\hline IHD & $62(6 \%)$ & $451(44 \%)$ & $48(36 \%)$ & $85(48 \%)$ & $175(39 \%)$ & $143(53 \%)$ & $167(44 \%)$ & $237(45 \%)$ & $47(38 \%)$ \\
\hline Prior Ml & $66(7 \%)$ & $247(24 \%)$ & $23(17 \%)$ & $53(30 \%)$ & $96(21 \%)$ & $75(28 \%)$ & $95(25 \%)$ & $130(24 \%)$ & $22(18 \%)$ \\
\hline Valve disease & $72(7 \%)$ & $359(35 \%)$ & $40(30 \%)$ & $51(29 \%)$ & $150(33 \%)$ & $118(43 \%)$ & $150(39 \%)$ & $166(31 \%)$ & $43(35 \%)$ \\
\hline Hypertension & $49(5 \%)$ & $555(53 \%)$ & 72 (54\%) & $98(55 \%)$ & $259(57 \%)$ & $126(46 \%)$ & $188(49 \%)$ & $292(55 \%)$ & $75(60 \%)$ \\
\hline Diabetes & $30(3 \%)$ & $278(27 \%)$ & $48(36 \%)$ & $60(34 \%)$ & $104(23 \%)$ & $66(24 \%)$ & 88 (23\%) & $156(29 \%)$ & $34(27 \%)$ \\
\hline \multicolumn{10}{|l|}{ Symptoms } \\
\hline $\begin{array}{l}\text { Breathless at rest or } \\
\text { minor activity }\end{array}$ & $69(7 \%)$ & $380(37 \%)$ & $49(32 \%)$ & $54(30 \%)$ & 177 (39\%) & $100(36 \%)$ & $145(38 \%)$ & $194(36 \%)$ & 41 (33\%) \\
\hline $\begin{array}{l}\text { Breathless markedly } \\
\text { limiting activity }\end{array}$ & & $404(39 \%)$ & $42(37 \%)$ & $71(40 \%)$ & $179(39 \%)$ & $112(41 \%)$ & $132(35 \%)$ & $217(41 \%)$ & $55(44 \%)$ \\
\hline $\begin{array}{l}\text { Moderate or severe } \\
\text { oedema }\end{array}$ & $104(10 \%)$ & $526(51 \%)$ & $64(48 \%)$ & 87 (49\%) & $224(49 \%)$ & $151(55 \%)$ & $183(48 \%)$ & $278(52 \%)$ & $65(52 \%)$ \\
\hline
\end{tabular}

Data are median and IOR or numbers and percentages of the population for age and sex.

*Excluding six patients in whom sex was not recorded (all $<75$ years), eight in whom age was not recorded (four women, four men) and six in whom admission ward was not recorded). IHD, ischaemic heart disease; LVEF, left ventricular ejection fraction; MI, myocardial infarction; NA, not applicable.

\section{Factors associated with discharge medications}

These were determined using a series of 10 logistic regression models and excluded patients who died during the index admission. Four variables (age $<75$ years, loop diuretics, history of hypertension and LVEF $<40 \%$ ) were independently associated with the prescription of either ACE inhibitors or A2RBs and were retained in all 10 models (table 8 ). Misclassification varied between $23 \%$ and $27 \%$. In the subset of patients with LVSD, three variables, namely age $<75$ years, loop diuretics and hypertension, were in all 10 models.

For use of $\beta$-blockers, three variables (age $<75$ years, loop diuretics, and history of hypertension) were retained in all 10 models (table 9).

Also frequently reported were male sex, history of myocardail infarction and having an echocardiogram whether or not it showed an LVEF $<40 \%$. Misclassification varied between $31 \%$ and $42 \%$. In the subset with LVSD, three variables, namely age $<75$ years, loop diuretics and myocardail infarction, were in all 10 models.

For the use of aldosterone antagonists, six variables (age $<75$ years, loop diuretics, male sex, history of valve disease, echo with LVEF $<40 \%$ and moderate/severe oedema) were retained in all 10 models (table 10). Misclassification varied between $26 \%$ and $30 \%$. In the subset with LVSD, three variables, (age $<75$ years, male sex, loop diuretics) were in all 10 models.

\section{Deaths during the index admission}

Overall, the mortality during the index hospitalisation was $12 \%$. Patients aged $<75$ years and those managed on cardiology wards had a mortality of $\sim 5 \%$ on the index admission, compared with a mortality of $>15 \%$ in other groups. Mortality was lowest (8\%) among those with LVEF $<40 \%$, higher $(11 \%)$ among those with LVEF $>40 \%$, perhaps due to the greater age of these patients, and highest among those without a recorded LVEF (18\%). In the 652 patients who died during the index admission, median time to death was 11 days (IOR 3-20) days. Patients admitted to a general medicine ward were more likely to die than those admitted to a cardiology ward $(\mathrm{HR}=2.5,95 \%$ CI 2.0 to 3.3 , $\mathrm{p}<0.001)$. This relationship remained significant in a multivariable model adjusting for age, aetiology, echocardiography, heart rhythm, sex and symptoms $(\mathrm{HR}=1.9,95 \% \mathrm{CI}=1.5$ to 2.5 , $\mathrm{p}<0.001$ ). Treatment (mainly recorded at discharge) was not included in these models.

\section{Deaths subsequent to discharge}

Median follow-up, censoring for death, was only 158 days (IOR $=70-260$ days) and maximum follow-up 365 days. Overall, $22 \%$ of patients who survived to discharge subsequently died. (figure $2 \mathrm{~A}-\mathrm{H}$ ). Younger patients and those who had been managed on cardiology wards fared better. The predicted annual mortality was close to $30 \%$, ranging from $10 \%$ in those aged $<65$ years up to $40 \%$ in those aged $>85$ years. Patients who did not have LVEF measured or who had LVEF above or below $40 \%$ had similar postdischarge mortality. Age but not sex appeared an important determinant of outcome. Patients discharged from general medicine wards were more likely to die than those discharged from cardiology wards $(\mathrm{HR}=1.4,95 \% \mathrm{CI} 1.2$ to 1.6 , 
Table 4 Characteristics of patients in whom LVEF was not reported by age, sex and admission ward

\begin{tabular}{|c|c|c|c|c|c|c|c|c|c|}
\hline Variable & $\begin{array}{l}\text { Missing } \\
\text { data* }\end{array}$ & Overall & $\begin{array}{l}\text { Women } \\
<75 \text { years }\end{array}$ & $\begin{array}{l}\text { Men } \\
<75 \text { years }\end{array}$ & $\begin{array}{l}\text { Women } \\
\geq 75 \text { years }\end{array}$ & $\begin{array}{l}\text { Men } \\
\geq 75 \text { years }\end{array}$ & Cardiology & $\begin{array}{l}\text { General } \\
\text { medicine }\end{array}$ & Other \\
\hline Numbers of patients & & 1523 & 165 (11\%) & $233(15 \%)$ & $638(42 \%)$ & $487(32 \%)$ & $342(22 \%)$ & $987(65 \%)$ & $194(13 \%)$ \\
\hline Women & NA & $800(53 \%)$ & NA & $\mathrm{NA}$ & NA & NA & $157(46 \%)$ & $531(54 \%)$ & $116(60 \%)$ \\
\hline Women $\geq 75$ years & & $638(42 \%)$ & NA & NA & NA & NA & $109(32 \%)$ & $435(44 \%)$ & $94(48 \%)$ \\
\hline Men $\geq 75$ years & & $487(32 \%)$ & NA & NA & NA & NA & $103(30 \%)$ & $330(33 \%)$ & $54(28 \%)$ \\
\hline General medicine & & $987(65 \%)$ & $95(58 \%)$ & $127(55 \%)$ & $435(68 \%)$ & $330(68 \%)$ & NA & NA & NA \\
\hline Other & & 194 (13\%) & $22(13 \%)$ & $24(10 \%)$ & $94(15 \%)$ & $54(11 \%)$ & NA & NA & NA \\
\hline \multicolumn{10}{|l|}{ Tests done } \\
\hline Sinus rhythm on ECG & $253(17 \%)$ & $464(30 \%)$ & $69(42 \%)$ & $86(37 \%)$ & $197(31 \%)$ & $112(23 \%)$ & $109(32 \%)$ & $296(30 \%)$ & $59(51 \%)$ \\
\hline \multicolumn{10}{|l|}{ Aetiology } \\
\hline IHD & $179(12 \%)$ & $620(41 \%)$ & $55(33 \%)$ & $95(41 \%)$ & $234(37 \%)$ & $236(48 \%)$ & $155(45 \%)$ & $387(39 \%)$ & $78(40 \%)$ \\
\hline Prior Ml & $206(14 \%)$ & $335(22 \%)$ & $29(18 \%)$ & $58(25 \%)$ & $120(19 \%)$ & $128(26 \%)$ & $95(28 \%)$ & $199(20 \%)$ & $41(21 \%)$ \\
\hline Valve disease & $328(22 \%)$ & $175(11 \%)$ & $21(13 \%)$ & $25(11 \%)$ & $75(12 \%)$ & $54(11 \%)$ & $50(15 \%)$ & $108(11 \%)$ & $17(9 \%)$ \\
\hline Hypertension & $207(14 \%)$ & $706(46 \%)$ & $86(52 \%)$ & $106(45 \%)$ & $309(48 \%)$ & $205(42 \%)$ & $156(46 \%)$ & $456(46 \%)$ & $94(48 \%)$ \\
\hline Diabetes & $129(8 \%)$ & $377(24 \%)$ & $62(38 \%)$ & $87(37 \%)$ & $116(18 \%)$ & $112(23 \%)$ & $94(27 \%)$ & $240(24 \%)$ & $43(22 \%)$ \\
\hline \multicolumn{10}{|l|}{ Symptoms } \\
\hline $\begin{array}{l}\text { Breathless at rest or } \\
\text { minor activity }\end{array}$ & $216(14 \%)$ & $438(29 \%)$ & $52(32 \%)$ & $66(28 \%)$ & $180(28 \%)$ & $140(29 \%)$ & $110(32 \%)$ & $273(28 \%)$ & $55(28 \%)$ \\
\hline $\begin{array}{l}\text { Breathless markedly } \\
\text { limiting activity }\end{array}$ & & $549(36 \%)$ & $57(35 \%)$ & $87(37 \%)$ & $211(33 \%)$ & $194(40 \%)$ & $117(34 \%)$ & $372(38 \%)$ & $60(31 \%)$ \\
\hline $\begin{array}{l}\text { Moderate or severe } \\
\text { oedema }\end{array}$ & $264(17 \%)$ & $672(44 \%)$ & $73(44 \%)$ & $110(47 \%)$ & $276(43 \%)$ & $213(44 \%)$ & $167(49 \%)$ & $419(42 \%)$ & $87(45 \%)$ \\
\hline
\end{tabular}

Data are median and IOR or numbers and percentages of the population for age and sex.

*Excluding six patients in whom sex was not recorded (all $<75$ years), eight in whom age was not recorded (four women, four men) and six in whom admission ward was not recorded). IHD, ischaemic heart disease; LVEF, left ventricular ejection fraction; Ml, myocardial infarction; NA, not applicable.

$\mathrm{p}<0.001)$. After adjustment for age, sex, aetiology, symptoms, treatment and investigation, a significant relationship still existed $(\mathrm{HR}=1.1,95 \%$ CI 1.0 to $1.3, \mathrm{p}=0.048)$. After further adjustment for follow-up by cardiology/heart failure services, this relationship was accounted for $(\mathrm{HR}=1.1,95 \% \mathrm{CI} 0.9$ to 1.2 , $\mathrm{p}=0.22$ ). A model excluding treatment ward identified greater age, greater severity of oedema, lack of use of an ACE inhibitor or $\mathrm{A} 2 \mathrm{RB}$ and lack of use of $\beta$-blockers as the strongest predictors of an adverse outcome (all $\mathrm{p}<0.001)$. LVEF did not predict outcome.

\section{Follow-up arrangements}

Most patients with LVEF $<40 \%$ regardless of age or management ward had cardiology or heart failure specialist nurse follow-up. Patients who were younger and managed on cardiology wards were also likely to have specialist follow-up even if their LVEF was $>40 \%$. A minority of patients were reported to have follow-up with care of the elderly or palliative care teams.

\section{Overall mortality}

Overall mortality, including deaths during the index admission, was $34 \%$ and the estimated 1 -year mortality was $>40 \%$. For those aged $<75$ years, the overall predicted annual mortality was $26 \%$ and for those aged $\geq 75$ years it was $56 \%$.

\section{DISCUSSION}

The most striking finding from this analysis is the poor overall prognosis of patients who require admission to hospital with a primary diagnosis of heart failure. This is substantially worse than data from clinical trials suggest, which may reflect the exclusion of older, frail and multimorbid patients and/or the survival benefit that appears to accrue from participating in clinical trials. ${ }^{10}$ Overall, $61 \%$ of patients were aged $\geq 75$ years. Age, rather than LVEF or sex, was the most important determinant of prognosis, although 1-year mortality was high (25\%) even in those aged $<75$ years, rising to $>50 \%$ in those aged $\geq 75$ years. These poor outcomes occurred in patients with LVEF $<40 \%$ despite fairly high uptake of guideline-indicated pharmacological treatment including ACE inhibitors or AR2Bs in $81 \%, \beta$-blockers in $59 \%$ and aldosterone antagonists in $37 \%$, although whether these were prescribed in appropriate doses is uncertain as this was not included in the analysis. There is room for improved implementation of existing pharmacological treatments, but this alone may not be enough to reduce annual mortality to a notional target of $<10 \%$ even in those aged $<75$ years.

This is the third substantial survey of heart failure deaths and discharges conducted in the UK. The EuroHeart Failure survey enrolled 1700 patients in a 6-week snapshot of UK hospital activity in 2001. ${ }^{11}$ It included patients with confirmed or suspected heart failure. These patients were slightly younger (mean age 75 years) than in the current survey but with similar sex and LVEF distribution. Only $21 \%$ of patients were managed on cardiology wards. Inpatient mortality was $9.1 \%$ and 12 week mortality $15.5 \%$. Use of ACE inhibitors or A2RBs was $55 \%$, 
Table 5 Treatment at discharge

\begin{tabular}{|c|c|c|c|c|c|c|c|c|c|}
\hline Variable & $\begin{array}{l}\text { Missing } \\
\text { data* }^{*}\end{array}$ & $\begin{array}{l}\text { Overall in } \\
\text { survivors }\end{array}$ & $\begin{array}{l}\text { Women } \\
<75 \text { years }\end{array}$ & $\begin{array}{l}\text { Men } \\
<75 \text { years }\end{array}$ & $\begin{array}{l}\text { Women } \\
\geq 75 \text { years }\end{array}$ & $\begin{array}{l}\text { Men } \\
\geq 75 \text { years }\end{array}$ & Cardiology & $\begin{array}{l}\text { General } \\
\text { medicine }\end{array}$ & Other \\
\hline Patients & & 5499 & 727 & 1549 & 1583 & 1640 & 2588 & 2420 & 491 \\
\hline Loop diuretic & 362 & 4744 (86\%) & $625(86 \%)$ & $1312(85 \%)$ & $1372(87 \%)$ & $1435(88 \%)$ & $2229(87 \%)$ & $2105(87 \%)$ & $410(84 \%)$ \\
\hline ACEI & 546 & $3400(62 \%)$ & 462 (64\%) & $1109(72 \%)$ & 851 (54\%) & 978 (60\%) & $1728(68 \%)$ & $1395(58 \%)$ & $277(56 \%)$ \\
\hline ARB & 966 & $716(13 \%)$ & 101 (14\%) & 197 (13\%) & $235(15 \%)$ & $183(12 \%)$ & 343 (13\%) & 317 (13\%) & $56(11 \%)$ \\
\hline ACEI or ARB & & $4073(74 \%)$ & 557 (77\%) & $1289(83 \%)$ & $1073(68 \%)$ & $1154(70 \%)$ & $2050(79 \%)$ & $1692(70 \%)$ & $331(67 \%)$ \\
\hline$\beta$-Blocker & 725 & $2760(50 \%)$ & $400(55 \%)$ & 993 (64\%) & 621 (39\%) & 746 (45\%) & $1613(63 \%)$ & $980(40 \%)$ & $167(34 \%)$ \\
\hline ARA & 794 & $1716(31 \%)$ & $236(32 \%)$ & $637(41 \%)$ & $361(23 \%)$ & $482(29 \%)$ & 987 (38\%) & $582(24 \%)$ & $147(30 \%)$ \\
\hline LVEF $<40 \%$ & & 3332 & 453 & 1174 & 696 & 1009 & 1920 & 1169 & 243 \\
\hline Loop diuretic & 107 & $2899(87 \%)$ & $384(85 \%)$ & 999 (85\%) & $624(90 \%)$ & 892 (88\%) & $1640(85 \%)$ & $1053(90 \%)$ & $206(85 \%)$ \\
\hline ACEI & 258 & $2286(69 \%)$ & $318(70 \%)$ & $879(75 \%)$ & $417(60 \%)$ & $672(67 \%)$ & $1353(70 \%)$ & $780(67 \%)$ & $153(63 \%)$ \\
\hline ARB & 507 & 441 (13\%) & $66(15 \%)$ & $146(12 \%)$ & $115(17 \%)$ & $114(11 \%)$ & $257(13 \%)$ & $156(13 \%)$ & $28(12 \%)$ \\
\hline ACEI or ARB & & 2701 (81\%) & $381(84 \%)$ & $1016(87 \%)$ & $523(75 \%)$ & $781(77 \%)$ & 1595 (83\%) & $926(79 \%)$ & $180(74 \%)$ \\
\hline$\beta$-Blocker & 336 & 1971 (59\%) & $285(63 \%)$ & 797 (68\%) & $345(50 \%)$ & $544(54 \%)$ & 1292 (67\%) & $582(50 \%)$ & $97(40 \%)$ \\
\hline ARA & 386 & $1230(37 \%)$ & $162(36 \%)$ & $527(45 \%)$ & $196(28 \%)$ & $345(34 \%)$ & 796 (41\%) & $339(29 \%)$ & $95(39 \%)$ \\
\hline LVEF $\geq 40 \%$ & & 937 & 128 & 169 & 407 & 233 & 364 & 465 & 108 \\
\hline Loop diuretic & 34 & 824 (88\%) & 117 (91\%) & 137 (81\%) & 357 (88\%) & 213 (91\%) & 324 (89\%) & $405(87 \%)$ & $95(88 \%)$ \\
\hline ACEI & 118 & 472 (50\%) & $67(52 \%)$ & 102 (60\%) & 191 (47\%) & 112 (48\%) & $193(53 \%)$ & $220(47 \%)$ & $59(55 \%)$ \\
\hline ARB & 187 & 127 (14\%) & 17 (13\%) & 24 (14\%) & $58(14 \%)$ & 28 (12\%) & $49(13 \%)$ & $64(14 \%)$ & $14(13 \%)$ \\
\hline ACEI or ARB & & 592 (63\%) & $84(66 \%)$ & $123(73 \%)$ & $246(60 \%)$ & $139(60 \%)$ & $239(66 \%)$ & $281(60 \%)$ & 72 (67\%) \\
\hline$\beta$-Blocker & 152 & 381 (41\%) & $61(48 \%)$ & $95(56 \%)$ & $135(33 \%)$ & $90(39 \%)$ & $178(49 \%)$ & $163(35 \%)$ & $40(37 \%)$ \\
\hline ARA & 160 & $246(26 \%)$ & $45(35 \%)$ & $52(37 \%)$ & $91(22 \%)$ & $58(25 \%)$ & $106(29 \%)$ & $114(25 \%)$ & $26(24 \%)$ \\
\hline No LVEF report & & 1230 & 146 & 206 & 480 & 398 & 304 & 786 & 140 \\
\hline Loop diuretic & 221 & 1021 (83\%) & $124(85 \%)$ & $176(85 \%)$ & 391 (81\%) & $330(83 \%)$ & $265(87 \%)$ & $647(82 \%)$ & $109(78 \%)$ \\
\hline ACEI & 170 & 642 (52\%) & 77 (53\%) & $128(62 \%)$ & $243(51 \%)$ & 194 (49\%) & 162 (53\%) & $395(50 \%)$ & $85(61 \%)$ \\
\hline ARB & 272 & 148 (12\%) & $18(12 \%)$ & 27 (13\%) & 62 (13\%) & 41 (10\%) & 37 (12\%) & 97 (12\%) & $14(10 \%)$ \\
\hline ACEI or ARB & & $780(63 \%)$ & $92(63 \%)$ & $150(73 \%)$ & $304(63 \%)$ & 234 (59\%) & $197(65 \%)$ & $485(62 \%)$ & $98(70 \%)$ \\
\hline$\beta$-Blocker & 237 & 408 (33\%) & $54(37 \%)$ & $101(49 \%)$ & $141(30 \%)$ & $112(28 \%)$ & $143(47 \%)$ & $235(30 \%)$ & $30(21 \%)$ \\
\hline ARA & 248 & $240(20 \%)$ & $29(20 \%)$ & $58(28 \%)$ & 74 (15\%) & 79 (20\%) & $85(28 \%)$ & $129(16 \%)$ & $26(19 \%)$ \\
\hline
\end{tabular}

Data are numbers (percentages) of the population surviving until discharge.

*Excluding 652 deaths on index admission and 20 patients with missing data on either sex, age or ward.

ACEl, ACE inhibitor; ARA, aldosterone receptor antagonist; ARB, angiotensin II receptor blocker; LVET, left ventricular ejection fraction.

Table 6 Outcomes for all patients and of the subgroup with LVEF $<40 \%$

\begin{tabular}{|c|c|c|c|c|c|c|c|c|c|}
\hline Variable & $\begin{array}{l}\text { Missing } \\
\text { data }\end{array}$ & Overall & $\begin{array}{l}\text { Women } \\
<75 \text { years }\end{array}$ & $\begin{array}{l}\text { Men } \\
<75 \text { years }\end{array}$ & $\begin{array}{l}\text { Women } \\
\geq 75 \text { years }\end{array}$ & $\begin{array}{l}\text { Men } \\
\geq 75 \text { years }\end{array}$ & Cardiology & $\begin{array}{l}\text { General } \\
\text { medicine }\end{array}$ & Other \\
\hline All patients* & & 6150 & $764(12 \%)$ & $1626(26 \%)$ & $1868(30 \%)$ & $1892(31 \%)$ & $2738(45 \%)$ & $2813(46 \%)$ & $599(10 \%)$ \\
\hline Hospital days $†$ & $387(7 \%)$ & $9(5-17)$ & $9(5-15)$ & $9(5-15)$ & $10(5-17)$ & $10(6-17)$ & $10(6-17)$ & $8(4-16)$ & $11(5-22)$ \\
\hline Discharges $^{*}$ & None & 5498 & $727(13 \%)$ & $1549(28 \%)$ & $1582(29 \%)$ & $1640(30 \%)$ & $2587(47 \%)$ & $2420(44 \%)$ & 491 (9\%) \\
\hline
\end{tabular}

Referral and outcome

\begin{tabular}{|c|c|c|c|c|c|c|c|c|c|}
\hline Cardiology/HF Services & $164(3 \%)$ & $3865(70 \%)$ & $561(77 \%)$ & 1317 (85\%) & $881(56 \%)$ & $1106(67 \%)$ & $2278(88 \%)$ & $1308(54 \%)$ & $279(57 \%)$ \\
\hline COTE & $586(11 \%)$ & $586(11 \%)$ & $59(8 \%)$ & $81(5 \%)$ & $247(16 \%)$ & $199(12 \%)$ & $77(3 \%)$ & $406(17 \%)$ & $103(21 \%)$ \\
\hline Palliative care & $496(9 \%)$ & $155(3 \%)$ & $13(2 \%)$ & $39(3 \%)$ & $46(3 \%)$ & $57(3 \%)$ & $75(3 \%)$ & $62(3 \%)$ & $18(4 \%)$ \\
\hline Deaths after discharge & None & $1206(22 \%)$ & $109(15 \%)$ & $210(14 \%)$ & $417(26 \%)$ & $470(29 \%)$ & $448(17 \%)$ & $623(26 \%)$ & $135(27 \%)$ \\
\hline Total deaths & None & $1858(34 \%)$ & $146(20 \%)$ & $287(19 \%)$ & 702 (44\%) & $722(44 \%)$ & $598(23 \%)$ & 1017 (42\%) & $243(49 \%)$ \\
\hline EF $<40 \% *$ & & 3590 & $466(13 \%)$ & $1216(34 \%)$ & $776(21 \%)$ & $1132(32 \%)$ & $2016(56 \%)$ & $1293(36 \%)$ & $281(8 \%)$ \\
\hline Hospital days† & $191(6 \%)$ & $9(6-17)$ & $9(6-17)$ & $9(6-15)$ & $10(6-18)$ & $10(6-18)$ & $10(6-16)$ & $9(5-16)$ & $12(7-24)$ \\
\hline Died on index admission & None & $258(8 \%)$ & $13(3 \%)$ & $42(4 \%)$ & $80(11 \%)$ & $123(12 \%)$ & $96(5 \%)$ & $124(11 \%)$ & $38(16 \%)$ \\
\hline Discharges* ${ }^{*}$ & None & 3332 & $453(14 \%)$ & $1174(35 \%)$ & $696(21 \%)$ & 1009 (30\%) & $1920(58 \%)$ & 1169 (35\%) & $243(7 \%)$ \\
\hline \multicolumn{10}{|l|}{ ferral and outcome } \\
\hline Cardiology/HF Services & $72(2 \%)$ & $2791(84 \%)$ & $402(89 \%)$ & $1064(91)$ & $515(74 \%)$ & $810(80 \%)$ & $1757(92 \%)$ & $849(73 \%)$ & $185(76 \%)$ \\
\hline COTE & $346(10 \%)$ & $296(8 \%)$ & $30(7 \%)$ & $51(4 \%)$ & $105(15 \%)$ & $110(11 \%)$ & $55(3 \%)$ & $191(16 \%)$ & $50(20 \%)$ \\
\hline Palliative care & $275(8 \%)$ & $105(3 \%)$ & $7(2 \%)$ & $31(3 \%)$ & $28(4 \%)$ & $39(4 \%)$ & $58(3 \%)$ & $36(3 \%)$ & $11(4 \%)$ \\
\hline Deaths after discharge & None & $677(20 \%)$ & $66(15 \%)$ & $148(12 \%)$ & $187(27 \%)$ & $276(27 \%)$ & $335(17 \%)$ & $277(24 \%)$ & $65(27 \%)$ \\
\hline Total deaths & None & $935(28 \%)$ & $79(17 \%)$ & $190(16 \%)$ & 267 (38\%) & $399(40 \%)$ & $431(22 \%)$ & $401(34 \%)$ & $103(42 \%)$ \\
\hline
\end{tabular}

Data excluding missing values for sex, age and ward.

Percentages are of the total in that column unless marked with an asterisk $\left(^{*}\right)$, in which case the percentage is of the total in the row.

†Median and IQR for stays $>24 \mathrm{~h}$. Overall, 682 patients $(11 \%)$ had an admission $<24 \mathrm{~h}$, which included deaths and patients with elective day-case procedures.

COTE, care of the elderly; HF, heart failure; LVEF, left ventricular ejection fraction. 
Table 7 Outcomes for all patients with LVEF $\geq 40 \%$ or no reported LVEF

\begin{tabular}{|c|c|c|c|c|c|c|c|c|c|}
\hline Variable & $\begin{array}{l}\text { Missing } \\
\text { data }\end{array}$ & Overall & $\begin{array}{l}\text { Women } \\
<75 \text { years }\end{array}$ & $\begin{array}{l}\text { Men } \\
<75 \text { years }\end{array}$ & $\begin{array}{l}\text { Women } \\
\geq 75 \text { years }\end{array}$ & $\begin{array}{l}\text { Men } \\
\geq 75 \text { years }\end{array}$ & Cardiology & $\begin{array}{l}\text { General } \\
\text { medicine }\end{array}$ & Other \\
\hline LVEF $\geq 40 \% *$ & & 1037 & $133(13 \%)$ & $177(17 \%)$ & $454(44 \%)$ & $273(27 \%)$ & $380(37 \%)$ & $533(51 \%)$ & $124(12 \%)$ \\
\hline Hospital days $\dagger$ & 60 & $10(6-17)$ & $11(6-18)$ & $9(6-16)$ & $10(6-16)$ & $9(5-17)$ & $10(6-17)$ & $9(5-17)$ & $13(7-23)$ \\
\hline Discharges* & & 942 & $128(14 \%)$ & $170(18 \%)$ & $407(43 \%)$ & $234(25 \%)$ & $364(39 \%)$ & $468(50 \%)$ & $110(12 \%)$ \\
\hline \multicolumn{10}{|l|}{ Referred to } \\
\hline Cardiology/HF Services & 26 & $553(59 \%)$ & $89(70 \%)$ & $125(74 \%)$ & $203(50 \%)$ & $136(58 \%)$ & $295(81 \%)$ & $211(45 \%)$ & 47 (35\%) \\
\hline Deaths after discharge & & $216(23 \%)$ & $22(17 \%)$ & $28(16 \%)$ & $98(24 \%)$ & $68(29 \%)$ & $58(16 \%)$ & $129(28 \%)$ & $29(21 \%)$ \\
\hline Total deaths & & $317(34 \%)$ & $27(21 \%)$ & $36(21 \%)$ & $145(36 \%)$ & $108(46 \%)$ & $74(20 \%)$ & $198(42 \%)$ & $45(33 \%)$ \\
\hline No LVEF report* & & 1523 & $165(11 \%)$ & $233(15 \%)$ & $638(42 \%)$ & 487 (32\%) & $342(22 \%)$ & 987 (65\%) & $194(13 \%)$ \\
\hline Hospital days $†$ & $136(9 \%)$ & $8(5-15)$ & $6(4-12)$ & $8(4-15)$ & $8(5-15)$ & $8(4-16)$ & $10(5-17)$ & $7(4-14)$ & $10(5-17)$ \\
\hline Died on index admission & None & $293(24 \%)$ & $19(13 \%)$ & $27(13 \%)$ & $158(33 \%)$ & $89(22 \%)$ & $38(13 \%)$ & $201(26 \%)$ & $54(39 \%)$ \\
\hline Discharges* & None & 1225 & $146(12 \%)$ & $205(17 \%)$ & $480(39 \%)$ & $397(32 \%)$ & $304(25 \%)$ & $783(64 \%)$ & $138(11 \%)$ \\
\hline Deaths after discharge & & $313(26 \%)$ & $21(14 \%)$ & $34(17 \%)$ & $132(28 \%)$ & $126(32 \%)$ & $55(18 \%)$ & $217(28 \%)$ & $41(30 \%)$ \\
\hline Total deaths & & $606(49 \%)$ & $40(27 \%)$ & $61(30 \%)$ & $290(60 \%)$ & $215(54 \%)$ & $93(31 \%)$ & $418(53 \%)$ & $95(69 \%)$ \\
\hline
\end{tabular}

Data excluding missing values for sex, age and ward.

Percentages are of the total in that column unless marked with an asterisk $\left(^{*}\right)$, in which case the percentage is of the total in the row.

† Median and IQR for stays $>24 \mathrm{~h}$. Overall, 682 patients $(11 \%)$ had an admission $<24 \mathrm{~h}$, which included deaths and patients with elective day-case procedures.

COTE, care of the elderly; HF, heart failure; LVEF, left ventricular ejection fraction.

$\beta$-blockers $24 \%$ and aldosterone antagonists $13.9 \%$. An NHS survey conducted in 2005-2006 enrolled 9387 patients with a mean age of 77 years. ${ }^{12}$ Inpatient mortality was $15 \%$. Use of ACE inhibitors or A2RBs was $71 \%, \beta$-blockers $39 \%$ and aldosterone antagonists $25 \%$. Comparing the surveys, use of heart failure medications appears to be increasing but the prognosis remains poor, perhaps in part due to the increasing age of the patients admitted.

Only $\sim 60 \%$ of the patients who should have been reported by participating hospitals were enrolled in this audit. Considering that the annual audit is still a work in prognosis, this rate of enrolment may be considered fair and the analysis relevant to contemporary clinical practice. Enrolment may have been biased towards younger patients and those managed on cardiology wards, although the age and sex distribution of patients was similar to two previous UK surveys of heart failure. ${ }^{11} 12$ Lack of availability of natriuretic peptides and diagnostic scepticism may have accounted for the relatively low rate of heart failure with preserved LVEF. ${ }^{13-15}$ As younger age and specialist management are associated with an increased probability of investigation, guideline-indicated management and prognosis, the real clinical situation may be worse than suggested by this survey. From April 2010, the audit should include all relevant hospitals and each should include at least 20 patients per month with a primary diagnosis of heart failure at death or discharge.

LVEF was not a strong determinant of prognosis and had a relatively small impact on the pattern of medication. Indeed, LVEF $<40 \%$ was associated with a somewhat better prognosis, at least in part because, as shown in other studies, it is more prevalent in younger patients and perhaps because these patients are more likely to receive specialist follow-up. The prognosis of older patients with a low LVEF may be so dismal that they are under-represented in prevalence statistics. Patients with LVEF $<40 \%$ were more likely to be treated with each class of drugs known to improve prognosis in patients with heart failure and this may also account, in part, for the better outcome among these patients. Although the evidence that ACE inhibitors, A2RBs, $\beta$-blockers and aldosterone antagonists should be given to patients with heart failure who have LVEF $>40 \%$ is not robust, they are often used to manage co-morbidities such as

Table 8 Factors associated with the use of ACEl/ARBs: logistic regression models using 10-fold crossvalidation for patients surviving to discharge

\begin{tabular}{|c|c|c|c|c|c|c|c|c|c|c|c|}
\hline \multirow[b]{2}{*}{ Variable } & \multicolumn{10}{|c|}{ Subset (excluding) } & \multirow{2}{*}{$\begin{array}{l}\text { No. of times } \\
\text { included }\end{array}$} \\
\hline & 1 & 2 & 3 & 4 & 5 & 6 & 7 & 8 & 9 & 10 & \\
\hline Age $<75$ years & + & + & + & + & + & + & + & + & + & + & 10 \\
\hline Loop diuretics & + & + & + & + & + & + & + & + & + & + & 10 \\
\hline Hypertension & + & + & + & + & + & + & + & + & + & + & 10 \\
\hline Echo with LVSD & + & + & + & + & + & + & + & + & + & + & 10 \\
\hline Sex (men) & & & & + & & & & & & & 10 \\
\hline Breathlessness & & & + & & & & & & & & 1 \\
\hline $\begin{array}{l}\text { Misclassification rate } \\
\text { on excluded subset (\%) }\end{array}$ & 25 & 24 & 24 & 26 & 24 & 24 & 23 & 27 & 23 & 26 & \\
\hline
\end{tabular}

+ means that a variable has been included in the model. Subset (excluding) 1 means all patients included except those in subset 1. Subset 1 was used to calculate a misclassification rate for model 1. etc.

ACEI, ACE inhibitor; ARB, angiotensin II receptor blocker; LVSD, left ventricular systolic dysfunction. 
Table 9 Factors associated with the use of $\beta$-Blockers: logistic regression models using 10 -fold crossvalidation for patients surviving to discharge

\begin{tabular}{|c|c|c|c|c|c|c|c|c|c|c|c|}
\hline \multirow[b]{2}{*}{ Variable } & \multicolumn{10}{|c|}{ Subset (excluding) } & \multirow{2}{*}{$\begin{array}{l}\text { No. of times } \\
\text { included }\end{array}$} \\
\hline & $\overline{1}$ & 2 & 3 & 4 & 5 & 6 & 7 & 8 & 9 & 10 & \\
\hline Age $<75$ years & + & + & + & + & + & + & + & + & + & + & 10 \\
\hline Loop diuretics & + & + & + & + & + & + & + & + & + & + & 10 \\
\hline Hypertension & + & + & + & + & + & + & + & + & + & + & 10 \\
\hline $\mathrm{Ml}$ & + & + & & + & + & + & + & + & + & + & 9 \\
\hline Sex (men) & + & & + & + & + & + & + & + & + & + & 9 \\
\hline Echo with LVSD & + & & + & + & + & + & + & + & + & + & 9 \\
\hline Echo without LVSD & + & + & + & + & & + & + & + & & + & 8 \\
\hline AF rhythm on ECG & & & + & & & & + & & & & 2 \\
\hline $\begin{array}{l}\text { Misclassification rate } \\
\text { on excluded subset }(\%)\end{array}$ & 34 & 33 & 35 & 42 & 36 & 31 & 34 & 38 & 34 & 35 & \\
\hline
\end{tabular}

+ means that a variable has been included in the model. Subset (excluding) 1 means all patients included except those in subset 1.

Subset 1 was used to calculate a misclassification rate for model 1, etc.

$A F$, atrial fibrillation; LVSD, left ventricular systolic dysfunction; MI, myocardial infarction.

ischaemic heart disease and hypertension and were widely used among such patients in this survey. ${ }^{16}$

Many patients had no LVEF reported. This is likely to reflect a mixture of underinvestigation and inadequate documentation of tests that were done. Measurement of natriuretic peptides provides a simple method of identifying patients who need investigation for heart failure and is a much better guide to prognosis than is LVEF. ${ }^{17}$ Despite National Institute for Health and Clinical Excellence (NICE) recommendations, ${ }^{18}$ these tests are not yet widely used in the UK $(<2 \%$ of patients in this survey), perhaps because of existing financial structures that often deal poorly with problems such as heart failure for which responsibility is often spread across multiple business units. It is also likely that the diagnosis of heart failure is often overlooked. Only about a quarter of patients discharged from hospital on a loop diuretic carry a discharge diagnosis of heart failure, and yet the prognosis of these patients is similarly poor whether or not heart failure is reported. ${ }^{4}$ Widespread use of natriuretic peptides would improve detection rates, which is a necessary first step towards improved management of heart failure.

Clearly, this analysis has many limitations including case ascertainment, robust data on doses of medications and use of devices. This reflects, in part, the limited resources available to complete the audit, which depended, in large part, on the good will and enthusiasm of existing health professionals rather than new funding. These issues will be addressed in the coming years. Currently, hospital provision of care is suboptimal and the outcome of patients poor. The same rules that apply to suspected cancer should pertain to a disease with such a malign prognosis as heart failure, including easy access to the first diagnostic step (natriuretic peptides), speedy referral to an appropriate specialist, with inpatient and postdischarge management guided by appropriately trained specialist staff. The current system of care already provides care to all patients with heart failure, but this is often haphazard and disorganised. Re-organisation of existing resources, rather than new funding, will be key to success. Development of dedicated inpatient resources to manage patients with heart failure, similar to the introduction of coronary care units in the previous century that have revolutionised the care of acute coronary syndromes, should be considered.

Clearly, more needs to be done to improve the prognosis of patients with heart failure. It is reasonable to assume that most deaths in younger patients and a substantial proportion in older patients were cardiovascular. There are many strategies to improve the outcome of patients with heart failure. For example, appropriate deployment of implantable cardiac defibrillator or cardiac resynchronisation devices has been associated with an annual mortality of $<5 \%$ in younger patients even with very poor left ventricular systolic function. ${ }^{19}$ Although our analysis did not include devices, it is very likely that they were deployed in only a small minority of patients. Many new pharmacological treatments directed at improving myocardial function are also in development, while interventions directed at key co-morbidities such as anaemia and renal impairment may

Table 10 Factors associated with the use of ARAs: logistic regression models using 10-fold crossvalidation for patients surviving to discharge

\begin{tabular}{|c|c|c|c|c|c|c|c|c|c|c|c|}
\hline \multirow[b]{2}{*}{ Variable } & \multicolumn{10}{|c|}{ Subset (excluding) } & \multirow{2}{*}{$\begin{array}{l}\text { No. of times } \\
\text { included }\end{array}$} \\
\hline & 1 & 2 & 3 & 4 & 5 & 6 & 7 & 8 & 9 & 10 & \\
\hline Age $<75$ years & + & + & + & + & + & + & + & + & + & + & 10 \\
\hline Sex (men) & + & + & + & + & + & + & + & + & + & + & 10 \\
\hline Loop diuretics & + & + & + & + & + & + & + & + & + & + & 10 \\
\hline Valve disease & + & + & + & + & + & + & + & + & + & + & 10 \\
\hline Echo with LVSD & + & + & + & + & + & + & + & + & + & + & 10 \\
\hline Oedema & + & + & + & + & + & + & + & + & + & + & 10 \\
\hline HF & & & & + & & & & & & & 1 \\
\hline Echo without LVSD & & + & & & & & & & & & 1 \\
\hline $\begin{array}{l}\text { Misclassification rate on excluded } \\
\text { subset (\%) }\end{array}$ & 27 & 28 & 28 & 27 & 27 & 29 & 28 & 30 & 27 & 26 & \\
\hline
\end{tabular}

+ means that a variable has been included in the model. Subset (excluding) 1 means all patients included except those in subset 1. Subset 1 was used to calculate a misclassification rate for model 1, etc.

$\mathrm{AF}$, atrial fibrillation; ARA, aldosterone receptor agonist; HF, diagnosis of heart failure; LVSD, left ventricular systolic dysfunction. 

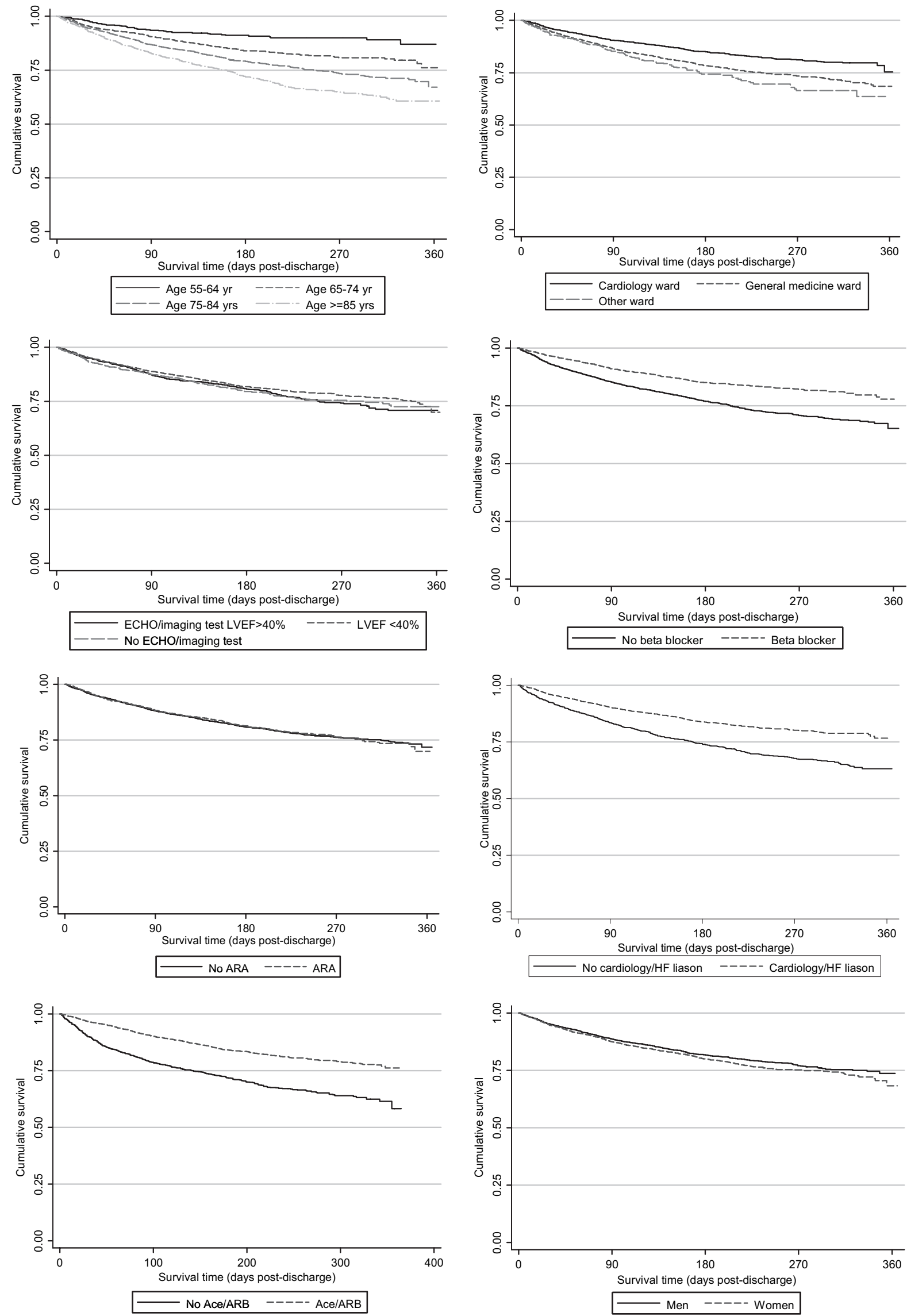

Figure $2(A-H)$ A series of Kaplan-Meier curves showing mortality subsequent to discharge according to $(A)$ age, $(B)$ sex, $(C)$ management ward (D) left ventricular ejection fraction (LVEF), (E) use of ACE inhibitors or angiotensin II receptor blockers (A2RBs), (F) use of $\beta$-blockers, (G) use of aldosterone antagonists (ARAs) and $(\mathrm{H})$ according to whether or not patients were referred into a specialist follow-up programme. 
also improve outcomes. Just as for acute coronary syndromes, the development of heart failure units will improve the deployment of existing treatments and accelerate the identification of new ones.

Perhaps the most important finding in this audit is that specialist care, both in the hospital and subsequent to discharge, is associated with better outcomes. This was not explained by differences in age, sex, LVEF, co-morbidity or discharge medication. This is consistent with data from randomised controlled trials, suggesting that intensified long-term management has a powerful effect on mortality. ${ }^{20} 21$ This may reflect better patient education and greater care with the titration and monitoring of treatment. Current evidence suggests that higher rates of prescription of evidence-based medicines especially ACE inhibitors, $\beta$-blockers and aldosterone antagonists, ${ }^{18} 22$ together with, where appropriate, the use of cardiac resynchronisation therapy (CRT) and implantable cardioverter-defibrillators (ICDs) within a comprehensive multidisciplinary system of specialist care would substantially improve outcomes. Audits such as this one continue to draw attention to the deficiencies in the management of patients with heart failure. Hopefully, future iterations of this audit will demonstrate sustained improvements in the quality of care, resulting in improved survival.

Acknowledgements We acknowledge the efforts made by the staff of participating hospitals that entered information into the national audit database and to all the staff of the NHS Information Centre who assisted with implementation.

Competing interests None.

Ethics approval This study was conducted with the approval of the NHS Information Centre.

Contributors Each of the authors helped in the planning and execution of the audit. ASR, AY and JGFC analysed the data. All authors contributed to the writing and revision of the manuscript.

Provenance and peer review Not commissioned; externally peer reviewed.

\section{REFERENCES}

1. HES online. 2010. http://www.hesonline.nhs.uk

2. NHS Institute for Innovation and Improvement. 2010. http://www.institute.nhs. uk/quality_and_service_improvement_tools/quality_and_service improvement tools/length.

3. Khand AU, Shaw M, Gemmel I, et al. Do discharge codes underestimate hospitalisation due to heart failure? Validation study of hospital discharge coding for heart failure. Eur J Heart Fail 2005;7:792-7.
4. Cleland JG, Yassin A, Arrow Y, et al. Outcome of patients discharged on loop diuretic therapy with or without a diagnosis of heart failure. Eur $J$ Heart Fail Supplement 2009.

5. Murray GD. A cautionary note on selection of variables in discriminant analysis. App/ Stat 1977;26:246-50.

6. Miller AJ. Selection of subsets of regression variables (with discussion). J R Stat Soc Ser A 1984;147:389-425.

7. Mantel N. Why stepdown procedures in variable selection. Technometrics 1970;12:621-5

8. Sauerbrei $\mathbf{W}$. The use of resampling methods to simplify regression models in medical statistics. App/ Stat 1999;48:313-29.

9. Schoenfeld D. Partial residual estimation for the proportional hazards regression. Biometrika 1982;69:239-41.

10. Clark AL, Lammiman MJ, Goode K, et al. Is taking part in clinical trials good for your health? Eur J Heart Fail 2009:11:1078-83.

11. Cleland JGF, Swedberg K, Follath F, et al. The Euroheart Failure Survey Programme: survey on the quality of care among patients with heart failure in Europe. Part 1 : patient characteristics and diagnosis. Eur Heart J 2003;24:422-63.

12. Nicol ED, Fitall B, Roughton M, et al. NHS Heart Failure Survey-a survey of acute heart failure admissions in England, Wales and Northern Ireland. Heart 2008;94:172-7.

13. Cleland JGF, Tendera M, Taylor J. Prognosis in heart failure with a normal ejection fraction. N Engl J Med 2007;357:829-30.

14. Caruana L, Petrie MC, Davie AP, et al. Do patients with suspected heart failure and preserved left ventricular systolic function suffer from "diastolic heart failure" or from misdiagnosis? A prospective descriptive study. BMJ 2000;321:215-18.

15. Petrie MC, Hogg K, Caruana L, et al. Poor concordance of commonly used echocardiographic measures of left ventricular diastolic function in patients with suspected heart failure but preserved systolic function: is there a reliable echocardiographic measure of diastolic dysfunction? Heart 2004;90:511-17.

16. Lenzen MJ, Scholte op Reimer WJM, Boersma E, et al. Differences between patients with a preserved and a depressed left ventricular function: a report from the EuroHeart Failure Survey. Eur Heart J 2004;25:1214-20.

17. Cleland JG, McMurray JJ, Kjekshus J, et al. Plasma concentration of aminoterminal pro-brain natriuretic peptide in chronic heart failure: prediction of cardiovascular events and interaction with the effects of rosuvastatin: a report from CORONA (Controlled Rosuvastatin Multinational Trial in Heart Failure). J Am Coll Cardiol 2009:54:1850-9.

18. National Institute for Health and Clinical Exellence. 2008. http://www.nice. org.uk/.

19. Moss AJ, Hall WJ, Cannom DS, et al. Cardiac-resynchronization therapy for the prevention of heart-failure events. N Engl J Med 2009;361:1329-38.

20. Clark RA, Inglis SC, McAlister FA, et al. Telemonitoring or structured telephone support programmes for patients with chronic heart failure: systematic review and meta-analysis. BMJ 2007:334:942.

21. Cleland JGF, Louis AA, Rigby AS, et al; on behalf of the TEN-HMS investigators. Noninvasive home telemonitoring for patients with heart failure at high risk of recurrent admission and death. The Trans-European Network-Home-Care Management System (TEN-HMS) Study. J Am Coll Cardiol 2005;45:1654-64.

22. Dickstein K, Cohen-Solal A, Filippatos G, et al. ESC guidelines for the diagnosis and treatment of acute and chronic heart failure 2008: the Task Force for the diagnosis and treatment of acute and chronic heart failure 2008 of the European Society of Cardiology. Developed in collaboration with the Heart Failure Association of the ESC (HFA) and endorsed by the European Society of Intensive Care Medicine (ESICM). Eur $J$ Heart Fail 2008;10:933-89. 